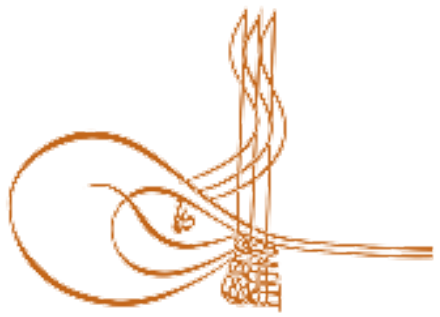

www.turkishstudies.net/education
Turkish Studies - Educational Sciences

eISSN: $2667-5609$

Research Article / Araștırma Makalesi

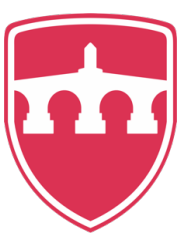

INTERNATIONAL

BALKAN

UNIVERSITY

Sponsored by IBU

\title{
Çevresel Vatandaşlık Bilgi Testinin Geliştirilmesi ve Ortaokul Öğrencilerinin Bilgi Düzeylerinin Belirlenmesi
}

\author{
Developing Environmental Citizenship Knowledge Test and Determining the Knowledge Levels of \\ Secondary School Students
}

\author{
Erkan Çermik $^{*}$ - Behiye Akçay ${ }^{* *}$
}

\begin{abstract}
In this study, a theoretical, valid and reliable knowledge test was developed to measure the knowledge dimension of environmental citizenship in secondary school students. In addition, environmental knowledge levels of secondary school students were examined. The data were collected from a total of 255 secondary school students studying in the seventh and eighth grade ${ }^{1}$. Within the framework of environmental citizenship, a multiple-choice knowledge test consisting of 45 items was prepared in accordance with Bloom's taxonomy considering the secondary school environmental curriculum standards. As a result of the item and test statistics using the Classical Test Theory, items with item difficulty and item discrimination indexes at the desired level were selected. Content validity was taken into consideration in the selection of the item. As a result of the analysis, Environmental Citizenship Knowledge Test consisting of 25 items with average difficulty value of 0.54 and average discrimination value of 0.57 was obtained. The internal reliability coefficient of the test (KR20) was determined to be 0.85 . Findings showed that secondary school students' level of knowledge about the dissolution time of different substances in nature is low. The sub-dimension, where the students have the highest level of knowledge, is the Mindful Consumption-Conscious Consumer sub-dimension. However, it has been observed that knowledge levels on global warming and greenhouse effect are lower than other subdimensions. The fact that the lowest level of knowledge is the behavior towards environmental protection emphasizes the importance of environmental citizenship education. The test developed in the study is a valid and reliable scale to measure the knowledge dimension of environmental citizenship levels of secondary school students.
\end{abstract}

\footnotetext{
${ }^{1}$ Bu çalışma, İstanbul Üniversitesi-Cerrahpaşa Rektörlüğü Sosyal ve Beşeri Bilimler Araştırmaları Etik Kurulu Başkanlığı tarafından 03.12.2019 tarihinde verilen 74555795-050.01.04 sayılı karar ile onaylanmıştır.

* Doktora Öğrencisi, İstanbul Üniversitesi-Cerrahpaşa, Lisansüstü Eğitim Enstitüsü, Fen Bilgisi Eğitimi.

PhD Candidate, Istanbul University-Cerrahpaşa, Institude of Graduate Studies, Science Education.

ORCID 0000-0003-0929-3527

erkancermik@gmail.com

** Prof. Dr., İstanbul Üniversitesi-Cerrahpasa, Hasan Ali Yücel Eğitim Fakültesi, Matematik ve Fen Bilimleri Eğitimi Bölümü

Prof. Dr., Istanbul University-Cerrahpasa, Hasan Ali Yucel Faculty of Education, Department of Science Education

ORCID 0000-0002-0546-8759

bbezir@gmail.com
}

Cite as/ Atıf: Çermik, E. \& Akçay, B. (2020). Çevresel vatandaşlık bilgi testinin geliştirilmesi ve ortaokul öğrencilerinin bilgi düzeylerinin belirlenmesi, Turkish Studies - Education, 15(2), 731-750. https://dx.doi.org/10.29228/TurkishStudies.42112

Received/Geliş: 11 March/Mart 2020

Accepted/Kabul: 27 April/Nisan 2020

Copyright $(C$ INTAC LTD, Turkey
Checked by plagiarism software

Published/Yayın: 30 April/Nisan 2020

CC BY-NC 4.0 
Structured Abstract: Introduction and purpose of study: Individuals with an awareness of environmental citizenship, who have the necessary knowledge to combat the negative effects of human activity on climate and the environment and to overcome this unsustainable situation, can only be raised through education. In order to measure the knowledge dimension of environmental citizenship in secondary school students, the purpose of this study was to develop theoretically valid and reliable knowledge test. Additionally, environmental knowledge levels of secondary school students were examined.

Theoretical framework: Cognitive, affective, and behavioral sensitivity related to the environment begins in the preschool period and develops in primary education and takes shape until the end of university (Yucel and Morgil, 1998). Environmental citizenship, which encourages thinking about the nature of environmental problems, can be seen as the ultimate result of education for sustainability. Generations that have received environmental citizenship education should be trained to solve these problems, which address environmental degradation by addressing the existing environmental problems and necessary sustainability conditions and pose a threat to a sustainable life with development. Although all educators agree that the primary purpose of environmental education is the development of environmentalist behavior (environmental literacy; environmental citizenship), they cannot agree on the most effective methods of achieving this result (Uzun and Saglam, 2006). Part of the discussion concerns that environmental education should primarily encourage affective (attitudes and values) or cognitive (knowledge) learning. Educators emphasizing the concept of environmental literacy or citizenship as the main task of environmental education, sometimes ignore the scientific concepts component of environmental education. In particular, it seems that educators who advocate the development of "environmental values" or "environmentally responsible behaviors" do not sufficiently emphasize the importance of understanding of scientific environmental concepts (Artun, 2013).

Method: The data were collected from a total of 255 secondary school students studying in the seventh and eighth grade. Within the framework of environmental citizenship, a multiple-choice knowledge test consisting of 45 items was prepared in accordance with Bloom's taxonomy considering the secondary school environmental curriculum standards. As a result of the item and test statistics using the Classical Test Theory, items with item difficulty and item discrimination indexes at the desired level were selected. Content validity was taken into consideration in the selection of the item.

Findings: As a result of the item analysis, Environmental Citizenship Knowledge Test consisting of 24 items with average difficulty value of 0.54 and average discrimination value of 0.57 was obtained (Table 1). The internal reliability coefficient of the test (KR20) was determined to be 0.85 .

Table 1: Difficulty and Discrimination Indices of the Items

\begin{tabular}{ccccccccc}
\hline Item & $\mathbf{P}_{\mathbf{j}}$ & $\mathbf{r}_{\mathbf{j} \mathbf{x}}$ & $\mathbf{I t e m}$ & $\mathbf{P}_{\mathbf{j}}$ & $\mathbf{r}_{\mathbf{j} \mathbf{}}$ & Item & $\mathbf{P j}$ & $\mathbf{r}_{\mathbf{j} \mathbf{x}}$ \\
\hline 1 & 0,66 & 0,28 & $\mathbf{1 6}$ & $\mathbf{0 , 5 5}$ & $\mathbf{0 , 4 1}$ & $\mathbf{3 1}$ & $\mathbf{0 , 5 5}$ & $\mathbf{0 , 6 4}$ \\
2 & 0,30 & 0,35 & $\mathbf{1 7}$ & $\mathbf{0 , 6 3}$ & $\mathbf{0 , 6 5}$ & 32 & 0,10 & $-0,06$ \\
3 & 0,25 & 0,14 & 18 & 0,14 & $-0,16$ & $\mathbf{3 3}$ & $\mathbf{0 , 5 5}$ & $\mathbf{0 , 8 4}$ \\
4 & 0,99 & 0,03 & $\mathbf{1 9}$ & $\mathbf{0 , 4 7}$ & $\mathbf{0 , 5 1}$ & $\mathbf{3 4}$ & $\mathbf{0 , 4 3}$ & $\mathbf{0 , 4 2}$ \\
5 & 0,62 & 0,00 & & & & $\mathbf{3 5}$ & $\mathbf{0 , 5 5}$ & $\mathbf{0 , 4 3}$ \\
6 & 0,12 & 0,01 & 21 & 0,38 & 0,36 & $\mathbf{3 6}$ & $\mathbf{0 , 5 3}$ & $\mathbf{0 , 3 9}$ \\
7 & 0,30 & 0,19 & $\mathbf{2 2}$ & $\mathbf{0 , 5 3}$ & $\mathbf{0 , 6 2}$ & $\mathbf{3 7}$ & $\mathbf{0 , 4 7}$ & $\mathbf{0 , 5 7}$ \\
$\mathbf{8}$ & $\mathbf{0 , 3 9}$ & $\mathbf{0 , 4 1}$ & 23 & 0,22 & 0,03 & $\mathbf{3 8}$ & $\mathbf{0 , 5 7}$ & $\mathbf{0 , 7 0}$ \\
9 & 0,47 & 0,33 & $\mathbf{2 4}$ & $\mathbf{0 , 6 9}$ & $\mathbf{0 , 5 7}$ & $\mathbf{3 9}$ & $\mathbf{0 , 4 1}$ & $\mathbf{0 , 6 4}$ \\
$\mathbf{1 0}$ & $\mathbf{0 , 4 3}$ & $\mathbf{0 , 4 6}$ & $\mathbf{2 5}$ & $\mathbf{0 , 5 2}$ & $\mathbf{0 , 6 1}$ & 40 & 0,32 & 0,20 \\
11 & 0,36 & 0,32 & $\mathbf{2 6}$ & $\mathbf{0 , 5 9}$ & $\mathbf{0 , 7 7}$ & 41 & 0,38 & 0,36 \\
12 & 0,26 & 0,12 & $\mathbf{2 7}$ & $\mathbf{0 , 6 5}$ & $\mathbf{0 , 6 4}$ & 42 & 0,30 & 0,30 \\
$\mathbf{1 3}$ & $\mathbf{0 , 5 3}$ & $\mathbf{0 , 5 7}$ & $\mathbf{2 8}$ & $\mathbf{0 , 5 7}$ & $\mathbf{0 , 5 7}$ & 43 & 0,33 & 0,14 \\
$\mathbf{1 4}$ & $\mathbf{0 , 7 4}$ & $\mathbf{0 , 4 1}$ & $\mathbf{2 9}$ & $\mathbf{0 , 5 0}$ & $\mathbf{0 , 5 1}$ & 44 & 0,33 & 0,23 \\
$\mathbf{1 5}$ & $\mathbf{0 , 5 0}$ & $\mathbf{0 , 6 2}$ & $\mathbf{3 0}$ & $\mathbf{0 , 6 2}$ & $\mathbf{0 , 7 1}$ & 45 & 0,25 & 0,09 \\
\hline \multicolumn{7}{c}{ Mean } & 0,46 & 0,38 \\
\hline
\end{tabular}

Findings showed that secondary school students' level of knowledge about the dissolution time of different substances in nature is low. The sub-dimension, where the students have the highest level of knowledge, is the Mindful Consumption-Conscious Consumer sub-dimension. However, it has been observed that knowledge levels on global warming and greenhouse effect are lower than other sub-dimensions. The fact 
that the lowest level of knowledge is the behavior towards environmental protection emphasizes the importance of environmental citizenship education. The test developed in the study is a valid and reliable scale to measure the knowledge dimension of environmental citizenship levels of secondary school students.

Conclusion and recommendations: In this study, the knowledge of seventh and eighth grade students within the scope of environmental citizenship was measured. The results show that the level of knowledge of the children participating in the research is medium. Students have less knowledge about global warming and greenhouse gas than other subjects. This result may be due to the fact that the issue of global warming and greenhouse gas will be seen in the eighth grade. Another issue that students have knowledge below medium in recycling. According to these results, it can be said that the contribution of formal education to the level of knowledge is not very high. Generally speaking, it can be said that students' knowledge is insufficient. Although behavioral change and development are the primary goals of many teaching programs, a clear understanding of how best to achieve these goals is still developing. The concept of environmental citizenship is generally perceived by individuals as sensitivity to environmental problems and responsible environmental behavior. This narrow perspective neglects the importance of conceptual knowledge about environmental problems. The findings of this study partially overlap with the findings of the studies in the literature. It has also been argued that students' knowledge of environmental concepts increases with their age (Erdogan, 2009). The Environmental Citizenship Knowledge Test that was developed in this study is a valid and reliable scale to measure the knowledge dimension of environmental citizenship levels of secondary school students. The Environmental Citizenship Knowledge Test meets the need for a measurement tool with sound psychometric properties, expressed by various researchers in environmental education. The knowledge test can be used in various research environments, and will enable the results of these studies to be comparable.

Keywords: Science Education, Environmental Citizenship, Environmental Knowledge Test, Global Warming, Sustainability.

Öz: Bu çalışmada ortaokul öğrencilerinde çevresel vatandaşlığın bilgi boyutunu ölçmek için teorik temelli, geçerli ve güvenilir bir bilgi testi geliştirilmiştir. Ayrıca, ortaokul öğrencilerinin çevre bilgi düzeyleri incelenmiștir. Veriler, yedinci ve sekizinci sınıfta eğitim gören toplam 255 ortaokul öğrencisinden toplanmıştır. Çevresel vatandaşlık çerçevesinde ortaokul çevre kazanımları dikkate alınarak Bloom taksonomisine uygun olarak 45 maddeden oluşan çoktan seçmeli bir bilgi testi hazırlanmıştır. Klasik Test Kuramı kullanılarak yapılan madde ve test istatistikleri sonucunda madde güçlük ve madde ayırt edicilik indeksleri istenilen seviyede olan maddeler seçilmiştir. Madde seçiminde kapsam geçerliği dikkate alınmıştır. Analiz sonucunda toplam 24 maddeden oluşan ve ortalama güçlük değeri 0.54, ortalama ayırt edicilik değeri ise 0.57 olan Çevresel Vatandaşlık Bilgi Testi elde edilmiştir. Testin iç güvenirlik katsayısı (KR20) 0.85 olarak tespit edilmiştir. Geliştirilen testten elde edilen bulgular, ortaokul öğrencilerinin farklı maddelerin doğada çözünme sürelerine ilișkin bilgi düzeyinin düşük olduğunu göstermiştir. Öğrencilerin bilgi düzeylerinin en yüksek olduğu alt boyut Tasarruf-Bilinçli Tüketici alt boyutudur. Ancak, küresel 1sınma ve sera etkisi konusundaki bilgi düzeylerinin diğer alt boyutlara göre daha düşük olduğu görülmüştür. Bilgi düzeyinin en düşük olduğu alt boyutun çevre korumaya yönelik davranışlar olması çevresel vatandaşlık eğitiminin önemini vurgulamaktadır. Çalışmada geliştirilen test ortaokul öğrencilerinin çevresel vatandaşlık düzeylerinin bilgi boyutunu ölçmek için geçerli ve güvenilir bir ölçektir.

Anahtar Kelimeler: Fen Eğitimi, Çevresel Vatandaşlık, Çevre Bilgi Testi, Küresel Isınma, Sürdürülebilirlik.

\section{Giriş}

Günümüzde gelişmiş ve gelişmekte olan ülkelerdeki insanların yaşam standartlarından ve teknolojideki hızlı üretimden dolayı yeryüzünün doğal kaynakları çok hızlı bir şekilde tüketilmektedir. Eşi görülmemiş ekonomik büyüme ve teknolojik ilerlemenin pek çok fayda sağladığı, ancak aynı zamanda ciddi sosyal ve çevresel sorunlara neden olduğu görülmüştür (MEB, 2013). İnsan faaliyetinin iklim ve çevre üzerine olan olumsuz etkileri ile mücadele etmek ve bu sürdürülemez olan gidişatın üstesinden gelmek için gerekli bilgi birikimi olan çevresel vatandaşlık bilinci gelişmiş bireyler ancak eğitim ile yetiştirilebilir. Çevre ile ilgili bilişsel, duyuşsal ve 
davranışsal duyarlılık okul öncesi dönemde başlayarak ilköğretim yıllarında gelişmeye başlar ve üniversite yıllarının sonuna kadar şekillenir (Yücel ve Morgil, 1998).

Küresel iklim değişikliği, biyolojik çeşitlilik kaybı ve kirlilik gibi mevcut bir dizi küresel çevre krizi, çevre vatandaşlı̆̆ını bir zorunluluk haline getirmiştir. Ülkemiz de diğer gelişmiş ve gelişmekte olan ülkeler gibi karmaşık çevresel sorunlar ile karşı karşıyadır. Çevre sorunlarının doğası hakkında düşünmeyi teşvik eden çevresel vatandaşlık, sürdürülebilirlik için eğitimin nihai sonucu olarak görülebilir. Mevcut çevre sorunlarını ve gerekli sürdürülebilirlik koşullarını ele alarak çevresel bozulmaya yol açan ve kalkınma ile birlikte sürdürülebilir bir yaşama tehdit oluşturan bu sorunların çözümü için çevresel vatandaşlık eğitimi almış nesiller yetiştirilmelidir.

Avrupa Bilim ve Teknoloji İşbirliği tarafindan desteklenen ve 38 ülkeden 120'den fazla uzmanın yer aldığı Avrupa Çevre Vatandaşlığı Ağına göre çevre vatandaşlığı şu şekilde tanımlanabilir (Hadjichambis ve Paraskeva-Hadjichambis, 2020: 4):

\begin{abstract}
"Çağdaş çevre sorunlarının çözümü doğrultusunda bireysel ve toplu eylemler yoluyla yerel, ulusal ve küresel ölçekte değişimin aracıları olarak yeni çevre sorunlarının yaratılmasının önlenmesi, sürdürülebilirliğin sağlanması ve doğa ile sağlıklı bir ilişkinin geliştirilmesi için topluma katılan vatandaşların sorumlu çevresel davranışlarıdır. Çevresel Vatandaşlık, çevresel haklar ve görevlerin uygulanmasının yanı sıra çevresel bozulma ve çevresel sorunların altında yatan yapısal nedenlerin tanımlanmasını, bu yapısal nedenleri ele almak için kritik ve aktif katılım ve sivil katılım yeterliliklerinin geliştirilmesini, demokratik yollarla bireysel ve toplu hareket etmeyi de içerir."
\end{abstract}

Dünya devletleri çevre eğitiminin ve halkın bilinçlendirilmesinin önemini kabul etmiştir (UNCED 1992). Birçok ülke çevre eğitimini müfredatlarının bir parçası yapmıştır. Avrupa'daki 42 ulusal ve yerel eğitim sistemine bakıldığında çevrenin korunmasına ilişkin eğitim 24 eğitim sisteminde ilkokul düzeyinde, 21 eğitim sisteminde ortaokul düzeyinde, 20 eğitim sisteminde lise düzeyinde ve 19 eğitim sisteminde ortaöğretim mesleki eğitim müfredatına dâhil edilmiştir (Cheah ve Huang, 2019). Ülkemizde de çevre eğitimi ilkokul, ortaokul ve lise müfredatlarında sarmallık ilkesi çerçevesinde verilmektedir. Çevre eğitimi konuları öğretim kademesine göre hayat bilgisi, fen ve teknoloji, sosyal bilgiler, biyoloji ve coğrafya gibi derslerde ele alınmakta ve sınıf içi etkinliklerin yanı sıra uygulamalı doğa ve laboratuvar etkinlikleri ile birlikte verilmektedir. Çevre eğitiminin farklı sınıf düzeylerinde öğrencilerin bilgi, tutum ve davranışlarına olan etkileri çeşitli çalışmalara konu edilmiştir (Erentay, 2013; Şahin ve Yazgan, 2013). Ancak, çevre vatandaşlığı hiçbir zaman eğitim sistemlerinin merkezinde yer almamıştır ve bu nedenle çevre vatandaşlığına açık bir şekilde odaklanmaya ve daha iyi çevresel sonuçlara ulaşmak için donanımlı ve motive olmuş bireylere ihtiyaç vardır (Schild, 2016). Eğitim sistemleri ve okullar gençlerin daha aktif, katılımcı ve sorumluluk sahibi çevreci vatandaş olmalarına büyük katkı sağlayacaktır (Hadjichambis ve ark., 2019). Çevresel vatandaşlık eğitiminin davranış değişikliği ile insanların gezegenleri ile ilgili sorumluluk almalarına ve aynı zamanda daha sürdürülebilir bir yaşam tarzı geliştirmelerine neden olacaktır (Hawthorne ve Alabaster, 1999). Sürdürülebilirliğe doğru ilerlemeye aktif katılım olarak tanımlanabilen çevresel vatandaşlık bilgi, beceri, tutum ve katılım olmak üzere önceden belirlenmiş dört bileşen çerçevesinde değerlendirilebilir (Hawthorne ve Alabaster, 1999; UNESCO-UNEP, 2010).

Bütün eğitimciler çevre eğitiminin birincil amacının çevreci davranışların geliştirilmesi (çevre okur-yazarlığı; çevresel vatandaşlık) olduğunu kabul etmelerine rağmen bu sonuca ulaşmanın en etkili yöntemlerinin ne olduğu konusunda anlaşamamaktadırlar (Uzun ve Sağlam, 2006). Tartışmanın bir kısmı, çevre eğitiminin öncelikle duyuşsal (yani, tutumlar ve değerler) veya bilişsel (yani bilgi) öğrenmeyi teşvik etmesi gerektiği ile ilgilidir. Çevre eğitiminin temel görevi olarak çevresel okuryazarlık ya da vatandaşlık kavramını vurgulayan eğitimciler zaman zaman çevre eğitiminin bilimsel kavramlar bileşenini görmezden gelmektedirler (Artun, 2013). Özellikle "çevre 
yanlısı değerlerin" veya "çevresel olarak sorumlu davranışların" geliştirilmesini savunan eğitimcilerin bilimsel çevre kavramları anlayışlarını yeterince vurgulamadıkları görülmektedir. Bunların yanı sıra insanların çevresel vatandaşlık geliştirebilmeleri için en önemli faktörlerden biri de çevre konuları ile ilgili bilimsel kavramlara sahip olmalarıdır. Bilimsel kavramsal anlayışa sahip olmanın önemi sıklıkla göz ardı edilebilmekte ve çevresel vatandaşlığın sosyal ve eylemsel boyutu öne çıkabilmektedir. Ancak, kavramsal bilgi sunumu önemlidir. Örneğin, insanlar kanalizasyon ve nehirler arasındaki bağlantıyı fark etmemektedir. Ekolojik sistemin nasıl çalıştığına dair daha geniş bir anlayışa sahip olmak ve daha büyük resmi anlamak için bilimsel kavramlara ihtiyaç vardır.

Çeşitli eğitim kademelerindeki öğrencilerin çevre kavramları ve çevresel sorunlar ile ilgili bilgi düzeylerini araştıran ulusal ve uluslararası birçok çalışma yapılmıştır. Ortaöğretim ve yükseköğretim öğrencilerinin çevre kavramları ve çevre soruları ile ilgili bilgi düzeylerinin yetersiz olduğu rapor edilmiştir (Yılmaz, Morgil, Aktug ve Göbekli, 2002). Öğretmen adaylarının da çevre konuları ile ilgili kavramsal gelişimlerinin yeterli olmadığı görülmüştür (Soran, Morgil, Yücel, Atav ve Iş̧1k, 2000). Bu çalışmaların hemen hepsi, öğrencilerin küresel ısınma, ozon tabakası incelmesi, biyoçeşitlilik kaybı gibi çevre sorunlarına yönelik konularda yetersiz bilgi düzeyine sahip olduklarını ve sorunlar ile ilgili kavram yanılgılarının olduğunu belirlemiştir (Atasoy, 2005; Bahar, 2000; Jeffries, Stanisstreet ve Boyes, 2001; Şahin ve Gül, 2009). Her eğitim kademesindeki öğrencilerin çevre kavram anlayışlarının yetersiz bilgi düzeyinde olması çevre vatandaşlığı eğitiminin önemini vurgulamakta ve bizleri çevre ile ilgili kavramsal bilgi düzeyini yükseltecek potansiyeli olan öğretim programları geliştirmeye yöneltmektedir.

$\mathrm{Bu}$ çalışmada, ortaokul öğrencilerinin çevresel vatandaşlık düzeylerinin bilgi bileşenini ölçmek için teorik temelli ve ampirik olarak onaylanmış geçerli ve güvenilir çoktan seçmeli bilgi testi geliştirmek amaçlanmıştır. Test formatının bu şekilde tercih edilmesinin en önemli sebebi kapsam geçerliği ve güvenirliğin yüksek olması ve hızlı bir şekilde objektif değerlendirmeye imkân tanımasıdır (Erkan ve Gömleksiz, 2014). Çevresel vatandaşlığı ölçmek için ampirik olarak onaylanmış ölçekler bulunmamaktadır. Bu nedenle, bu çalışmada ortaokul öğrencilerinden toplanan verilere dayanarak bilgi testinin geçerlik ve güvenirliği açıklanmıştır. Sonuç olarak, çevresel vatandaşlık bilgi testi araştırmacılara ve uygulayıcılara öğrencilerin çevre vatandaşlığını ölçmek ve değerlendirmek için bir araştırma aracı kullanma firsatı vererek önemli bir boşluğu dolduracaktır.

\section{Yöntem}

$\mathrm{Bu}$ çalışma kapsamında Çevresel Vatandaşlık Bilgi Testi geliştirme süreci, çevresel vatandaşlık hakkındaki mevcut alan yazının kapsamlı bir şekilde incelenmesi ve ortaokul programındaki çevre kazanımlarının çıkarılması ile başlamıştır. İki öğretim üyesi ve üç öğretmenden oluşan bir uzman grubu çevre vatandaşlığ 1 modelinin teorik arka planına ve programdaki kazanımlara dayalı olarak bir dizi madde geliştirmiştir. Bu maddeler kazanımlar ile ilgili ilk madde havuzunu oluşturmuştur. Daha sonra bu maddeler dört fen bilgisi öğretmeni ve bir dil uzmanı tarafından maddelerin okunabilirliğini ve anlaşılabilirliğini artırmak için gözden geçirilmiştir. Düzeltilmiş madde havuzundan belirtke tablosu da dikkate alınarak kapsam geçerliğine uygun olacak şekilde denemede kullanılacak test maddeleri seçilmiştir. Uygulama sonucunda madde analizi yapılmıştır. Çevresel Vatandaşlık Bilgi Testi analiz sonucunda psikometrik özellikleri uygun olan test maddeleri arasından içerik geçerliği dikkate alınarak seçilmiştir.

Araştırmanın amacı doğrultusunda karma yöntem araştırma tipolojilerinden sıralı keşfedici karma yöntem deseninden faydalanılmıştır (Creswell, 2013). Bu desende öncelikle nitel veriler toplanır ve analiz edilir. Elde edilen sonuçlardan yararlanılarak oluşturulan taslak form ile nicel veriler toplanır. Nicel verilerin analizi sonucunda ölçeğin son şekli oluşturulur. Çalışma yönteminin işlem basamakları Şekil 1'de verilmiştir. Araştırma verilerinin toplanmasında, yine araştırma kapsamında geliştirilen Çevresel Vatandaşlık Bilgi Testi kullanılmıştır. 


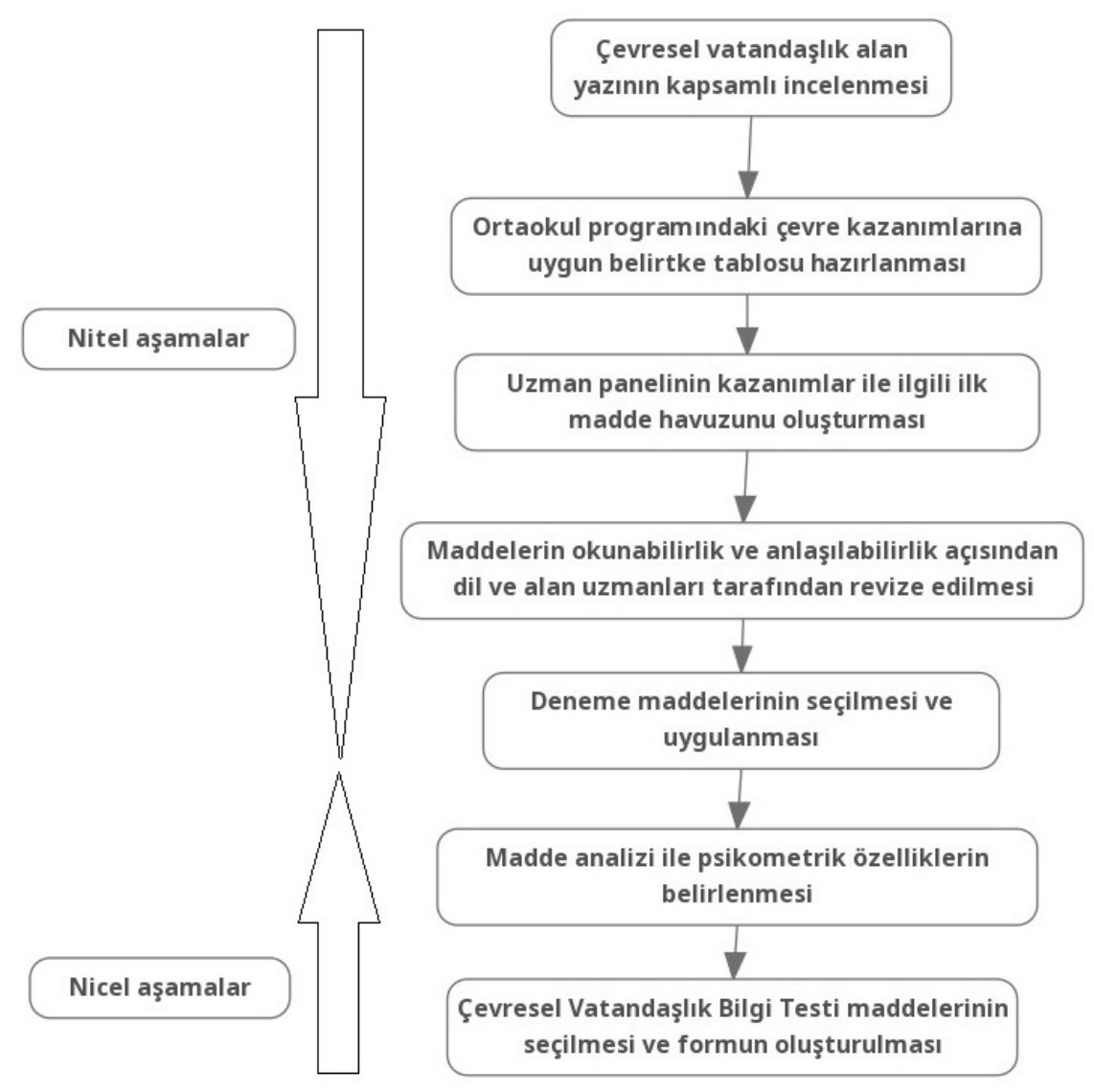

Şekil 1: Çalışmada Kullanılan Sıralı Keşfedici Karma Yöntem Deseni Basamakları

\section{Çalışma Grubu}

$\mathrm{Bu}$ araştırmanın verileri, İstanbul ili Güngören ilçesinde öğrenim gören 60 ortaokul yedinci sınıf öğrencisi, Beykoz İlçesinde öğrenim gören 75 ortaokul yedinci sınıf öğrencisi, 55 ortaokul sekizinci sınıf öğrencisi, Van ilinde öğrenim gören 45 ortaokul yedinci sınıf öğrencisi. 20 ortaokul sekizinci sınıf öğrencisi olmak üzere toplamda 255 ortaokul öğrencisinden toplanmıştır.

\section{Çevresel Vatandaşlık Bilgi Testi Geliştirme Süreci}

Genel olarak bilgi testi geliştirme süreci eğer test var olan bir öğretim programı için geliştiriliyor ise konunun ve konuya ait kazanımların belirlenmesiyle başlar. Bilgi testi eğer yeni bir program için hazırlanacaksa öncelikle kazanımlar yazılmalı ve sorular bu kazanımlara göre hazırlanmalıdır (Erkan ve Gömleksiz, 2014). Çevresel vatandaşlık henüz öğretim programlarına girmediği için bu çalışmada iki yöntem birden kullanılmıştır. Çevresel Vatandaşlık Bilgi Testini geliştirmek için öncelikle ilkokul ve ortaokul düzeyinde fen bilimleri öğretim programlarında yer alan çevre ile ilgili konu ve kazanımlar belirlenmiştir (Bkz Tablo 1). 3-8. sınıflar arasında çevresel vatandaşlıkla ilgili atıklar ve geri dönüşüm, bilinçli tüketici, kirlenme-çevreyi koruma (biyoçeşitlilik, insan çevre ilişkisi, yıkıcı doğa olayları, yakıtlar), küresel ısınma ve sera gazı (madde döngüleri ve sürdürülebilir kalkınma) başlıkları altında 25 kazanım bulunmaktadır (Bkz. Tablo 2). Kazanımların Bloom taksonomisine göre düzeyleri test maddeleri yazmaya başlamadan önce belirlenmiştir. Böylece soru düzeylerinin kazanım düzeylerine uygun olması sağlanmıştır. Her bir kazanım için 
kazanım düzeyi ile eşleşen aday üç test maddesini içeren belirtke tablosu hazırlanmıştır. Üst düzey (analiz, sentez ve değerlendirme) soruların birden çok kazanımı ölçecek biçimde hazırlanmıştır.

Tablo 1: MEB Fen Programları Çevresel Vatandaşlık Kazanımları

\begin{tabular}{|c|c|c|c|}
\hline Konu & Kazanımlar & $\begin{array}{c}\text { Taksonomi } \\
\text { Düzeyi }\end{array}$ & $\begin{array}{c}\text { Sinıf } \\
\text { Düzeyi }\end{array}$ \\
\hline \multirow{6}{*}{$\begin{array}{l}\text { Atıklar ve } \\
\text { Geri } \\
\text { Dönüşüum }\end{array}$} & $\begin{array}{l}\text { Pil atıklarının çevreye vereceği zararları ve bu konuda yapılması } \\
\text { gerekenleri tartışır. }\end{array}$ & Analiz & 3 \\
\hline & $\begin{array}{l}\text { Evsel atıklarda geri dönüştürülebilen ve dönüştürülemeyen } \\
\text { maddeleri ayırt eder. }\end{array}$ & Kavrama & 7 \\
\hline & Evsel katı ve sıvı atıkların geri dönüșümüne ilișkin proje tasarlar. & Sentez & 7 \\
\hline & Geri dönüşümü, kaynakların etkili kullanımı açısından sorgular. & Analiz & 7 \\
\hline & Yakın çevresinde atık kontrolüne özen gösterir. & Uygulama & 7 \\
\hline & $\begin{array}{l}\text { Yeniden kullanılabilecek eşyalarını, ihtiyacı olanlara iletmeye } \\
\text { yönelik proje geliştirir. }\end{array}$ & Sentez & 7 \\
\hline \multirow[b]{2}{*}{$\begin{array}{l}\text { Bilinçli } \\
\text { Tüketici }\end{array}$} & Kaynakların kullanımında tasarruflu davranmaya özen gösterir. & Uygulama & 4 \\
\hline & $\begin{array}{l}\text { Yaşam için gerekli olan kaynakların ve geri dönüşümün önemini } \\
\text { fark eder. }\end{array}$ & Bilgi & 4 \\
\hline \multirow{9}{*}{$\begin{array}{c}\text { Kirlenme ve } \\
\text { Çevreyi } \\
\text { Koruma }\end{array}$} & Biyoçeşitliliğin doğal yaşam için önemini sorgular. & Analiz & 5 \\
\hline & $\begin{array}{l}\text { Biyoçeşitliliği tehdit eden faktörleri, araştırma verilerine dayalı } \\
\text { olarak tartışır. }\end{array}$ & Analiz & 5 \\
\hline & İnsan ve çevre arasındaki etkileşimin önemini ifade eder. & Kavrama & 5 \\
\hline & $\begin{array}{l}\text { Yakın çevresindeki veya ülkemizdeki bir çevre sorununun } \\
\text { çözümüne ilişkin öneriler sunar. }\end{array}$ & Kavrama & 5 \\
\hline & $\begin{array}{l}\text { İnsan faaliyetleri sonucunda gelecekte oluşabilecek çevre } \\
\text { sorunlarına yönelik çıarımda bulunur. }\end{array}$ & Sentez & 5 \\
\hline & $\begin{array}{l}\text { İnsan-çevre etkileşiminde yarar ve zarar durumlarını örnekler } \\
\text { üzerinde tartışır. }\end{array}$ & Analiz & 5 \\
\hline & Doğal süreçlerin neden olduğu yıkıcı doğa olaylarını açıklar. & Kavrama & 5 \\
\hline & Yıkıcı doğa olaylarından korunma yollarını ifade eder. & Bilgi & 5 \\
\hline & $\begin{array}{l}\text { Farklı türdeki yakıtların 1sı amaçlı kullanımının, insan ve çevre } \\
\text { üzerine etkilerini tartışı. }\end{array}$ & Analiz & 6 \\
\hline \multirow{8}{*}{$\begin{array}{l}\text { Küresel } \\
\text { Isınma ve } \\
\text { Sera Gazı }\end{array}$} & Madde döngülerini şema üzerinde göstererek açıklar. & Kavrama & 8 \\
\hline & Madde döngülerinin yaşam açısından önemini sorgular. & Kavrama & 8 \\
\hline & $\begin{array}{l}\text { Küresel iklim değişikliklerinin nedenlerini ve olası sonuçlarını } \\
\text { tartışır. }\end{array}$ & Analiz & 8 \\
\hline & Kaynakların kullanımında tasarruflu davranmaya özen gösterir. & Uygulama & 8 \\
\hline & Kaynakların tasarruflu kullanımına yönelik proje tasarlar. & Sentez & 8 \\
\hline & $\begin{array}{l}\text { Geri dönüşüm için katı atıkların ayrıştırılmasının önemini } \\
\text { açılar. }\end{array}$ & Kavrama & 8 \\
\hline & $\begin{array}{l}\text { Geri dönüşümün ülke ekonomisine katkısına ilişkin araştırma } \\
\text { verilerini kullanarak çözüm önerileri sunar. }\end{array}$ & Sentez & 8 \\
\hline & $\begin{array}{l}\text { Kaynakların tasarruflu kullanılmaması durumunda gelecekte } \\
\text { karşılaşlabilecek problemleri belirterek çözüm önerileri sunar. }\end{array}$ & Sentez & 8 \\
\hline
\end{tabular}

Araştırmacı kazanımları ölçmeye yönelik öncelikle Bloom taksonomisine göre bilgi düzeyinde 18 , kavrama düzeyinde 20 , uygulama düzeyinde 18 ve analiz düzeyin 18 olmak üzere toplam 74 aday soru hazırlamıştır. Test maddeleri ardından üç fen bilimleri öğretmeni ve fen eğitimi alanında çevre konularında uzman bir öğretim üyesi tarafından kazanımlarla uyumluluk, konuya uygunluk, öğrenci seviyesine uygunluk, anlaşılırlık açılarından değerlendirilmiştir. $\mathrm{Bu}$ değerlendirmeler sonunda madde analizi çalışması için soru sayısı 45 olarak belirlenmiş̧ir. Gelen dönütler sonrası düzeltmeler yapıldıktan sonra yine öğrenci seviyesine uygunluğunun belirlenmesi 
için sorular 10 öğrenciye uygulanmıştır. İçerik geçerliliği, daha önce de belirtildiği gibi testin oluşturulmasına rehberlik etmiştir.

Tablo 2: Madde Analizi İçin Seçilen Soruların Konu ve Taksonomi Seviyeleri

\begin{tabular}{|c|c|c|c|c|c|}
\hline \multicolumn{3}{|c|}{ Madde analizine alınan soruların dağılımı } & & & \\
\hline Alt boyut & No & $\begin{array}{c}\text { Taksonomi } \\
\text { Seviyesi }\end{array}$ & Alt boyut & No & $\begin{array}{c}\text { Taksonomi } \\
\text { Seviyesi }\end{array}$ \\
\hline \multirow{13}{*}{ Geri Dönüşüm } & 1 & Bilgi & \multirow{11}{*}{$\begin{array}{l}\text { Kirlenme ve } \\
\text { Çevreyi } \\
\text { Koruma }\end{array}$} & 23 & Kavrama \\
\hline & 2 & Bilgi & & 24 & Bilgi \\
\hline & 3 & Bilgi & & 25 & Bilgi \\
\hline & 4 & Bilgi & & 26 & Kavrama \\
\hline & 5 & Kavrama & & 27 & Kavrama \\
\hline & 6 & Kavrama & & 28 & Kavrama \\
\hline & 7 & Uygulama & & 29 & Kavrama \\
\hline & 8 & Uygulama & & 30 & Uygulama \\
\hline & 9 & Uygulama & & 31 & Uygulama \\
\hline & 10 & Analiz & & 32 & Uygulama \\
\hline & 11 & Analiz & & 33 & Uygulama \\
\hline & 12 & Analiz & \multirow{12}{*}{$\begin{array}{l}\text { Küresel Isınma } \\
\text { ve Sera Gazı }\end{array}$} & 34 & Kavrama \\
\hline & 13 & Analiz & & 35 & Bilgi \\
\hline \multirow{10}{*}{$\begin{array}{l}\text { Tasarruf-Bilinçli } \\
\text { Tüketici }\end{array}$} & 14 & Bilgi & & 36 & Bilgi \\
\hline & 15 & Kavrama & & 37 & Kavrama \\
\hline & 16 & Kavrama & & 38 & Kavrama \\
\hline & 17 & Kavrama & & 39 & Uygulama \\
\hline & 18 & Uygulama & & 40 & Analiz \\
\hline & 19 & Uygulama & & 41 & Analiz \\
\hline & 20 & Uygulama & & 42 & Analiz \\
\hline & 21 & Analiz & & 43 & Analiz \\
\hline & 22 & Analiz & & 44 & Analiz \\
\hline & & & & 45 & Analiz \\
\hline
\end{tabular}

Çevresel Vatandaşlık Bilgi Testi dört önemli çevresel alanın (atıklar ve geri dönüşüm, bilinçli tüketici, kirlenme-çevreyi koruma, küresel 1sınma ve sera gazı) sistematik olarak örneklenmesi ile tasarlanmıştır. Aday test maddelerinden oluşan 45 soruluk test (Bkz. Tablo 2) çalışma grubundaki ortaokul öğrencilerine uygulanmıştır. Uygulama yapılacak öğrenci sayısının madde sayısının en az beş katı olması kuralına dikkat edilmiştir (Büyüköztürk, Kılıç Çakmak, Akgün, Karadeniz ve Demirel, 2017). 
Tablo 3: Son Test İçin Seçilen Soruların Konu ve Taksonomi Seviyeleri

\begin{tabular}{|c|c|c|}
\hline \multicolumn{3}{|c|}{ Madde Analizi Sonrası Soruların Dağılımı } \\
\hline Alt boyut & No & Taksonomi Seviyesi \\
\hline \multirow{3}{*}{ Geri Dönüşüm } & 1 & Uygulama \\
\hline & 2 & Analiz \\
\hline & 3 & Analiz \\
\hline \multirow{6}{*}{ Tasarruf-Bilinçli Tüketici } & 4 & Bilgi \\
\hline & 5 & Kavrama \\
\hline & 6 & Kavrama \\
\hline & 7 & Kavrama \\
\hline & 8 & Uygulama \\
\hline & 9 & Analiz \\
\hline \multirow{9}{*}{ Kirlenme-Çevreyi Koruma } & 10 & Bilgi \\
\hline & 11 & Bilgi \\
\hline & 12 & Kavrama \\
\hline & 13 & Kavrama \\
\hline & 14 & Kavrama \\
\hline & 15 & Kavrama \\
\hline & 16 & Uygulama \\
\hline & 17 & Uygulama \\
\hline & 18 & Uygulama \\
\hline \multirow{6}{*}{ Küresel Isınma ve Sera Gazı } & 19 & Kavrama \\
\hline & 20 & Bilgi \\
\hline & 21 & Bilgi \\
\hline & 22 & Kavrama \\
\hline & 23 & Kavrama \\
\hline & 24 & Uygulama \\
\hline
\end{tabular}

Madde analizi yapmak için seçilen 45 soru 255 ortaokul yedinci ve sekizinci sınıf öğrencisine uygulanmıştır. Uygulama sonunda soru seçimi için madde güçlük, madde ayırt edicilik ve KR20 testleri uygulanmıştır. Madde güçlük ve madde ayırt edicilik analizleri için öncelikle toplam puanlar hesaplanmış ve öğrencilerin yüksek not alandan düşük not alana doğru sıralanmıştır. Sonrasında en yüksek not alan yüzde 27 ile en düşük not alan yüzde 27'lik iki grup oluşturulmuştur. Madde güçlüğü için $\mathrm{Pj}=(\ddot{\mathrm{UstD}}+\mathrm{AltD}) / \mathrm{N}$ formülü, madde ayırt edicilik için $\mathrm{rjx}=(\ddot{\mathrm{U} s t D}-\mathrm{AltD}) / \mathrm{n}$ formülü kullanılmıştır. $\ddot{\text { sts }} \mathrm{D}=$ üst grupta doğru cevap verenler, $\mathrm{AltD}=$ alt grupta doğru cevap verenler, $\mathrm{n}=$ yüzde 27, N=yüzde 27+27'dir. Analizler sonucunda elde edilen madde güçlük ve madde ayırt edicilik indeksleri Tablo 4'te verilmiştir. Uzman panelinin önerisi üzerine yirmi numaralı maddenin son teste alınması uygun görülmemiştir. Bundan dolayı yirminci maddeye ait değerler tablodan çıkarılmıştır.

Madde güçlüğü, sorunun öğrenci için ne kadar zor olduğunu ifade eder. Güçlük, 0 ile +1 arasında değer alır, 1'e yaklaştıkça zor 0'a yaklaşıkça kolay demektir. Sorunun güçlüğüne testin amacına göre karar verilir, okul testlerinde ortalama güçlük (.40-.60) tercih edilir. Madde ayırt ediciliği, bir sorunun bilenle bilmeyeni ayırt etme gücünü ifade eder. Ayır edicilik -1 ile +1 arasında değer alır, değerin +1 'e yaklaşması sorunun ayırt edicilik gücünün yüksek olduğunu gösterir. Ayırt edicilik 0.40 üzerinde ise çok iyi, .30-.40 arasında ise iyi, .20-.30 arasında orta, .20'in altında ise kötü olarak yorumlanır (Erkan ve Gömleksiz, 2014). Aday maddelerin nihai teste seçimine öncelikle madde ayırt edicilik sonuçlarına ve sonrasında ise güçlüğe bakılarak karar verilmiştir. Madde seçimi yapılırken kapsam geçerliği de göz önüne alınmıştır. Madde seçimi yapıldıktan sonra testin son halinin güvenirlik analizleri de yapılmıştır. 
Tablo 4: Maddelerin Güçlük ve Ayırt Edicilik İndeksleri

\begin{tabular}{|c|c|c|c|c|c|c|c|c|}
\hline $\begin{array}{c}\text { Mad. } \\
\text { no }\end{array}$ & $\mathbf{P j}$ & $\mathbf{r j x}$ & $\begin{array}{c}\text { Mad. } \\
\text { no }\end{array}$ & $\mathbf{P j}$ & $\mathbf{r j x}$ & $\begin{array}{c}\text { Mad. } \\
\text { no }\end{array}$ & Pj & rjx \\
\hline 1 & 0,66 & 0,28 & $\mathbf{1 6}$ & $\mathbf{0 , 5 5}$ & $\mathbf{0 , 4 1}$ & $\mathbf{3 1}$ & $\mathbf{0 , 5 5}$ & $\mathbf{0 , 6 4}$ \\
\hline 2 & 0,30 & 0,35 & $\mathbf{1 7}$ & $\mathbf{0 , 6 3}$ & $\mathbf{0 , 6 5}$ & 32 & 0,10 & $-0,06$ \\
\hline 3 & 0,25 & 0,14 & 18 & 0,14 & $-0,16$ & $\mathbf{3 3}$ & $\mathbf{0 , 5 5}$ & $\mathbf{0 , 8 4}$ \\
\hline 4 & 0,99 & 0,03 & $\mathbf{1 9}$ & $\mathbf{0 , 4 7}$ & $\mathbf{0 , 5 1}$ & $\mathbf{3 4}$ & $\mathbf{0 , 4 3}$ & $\mathbf{0 , 4 2}$ \\
\hline 5 & 0,62 & 0,00 & & & & $\mathbf{3 5}$ & $\mathbf{0 , 5 5}$ & $\mathbf{0 , 4 3}$ \\
\hline 6 & 0,12 & 0,01 & 21 & 0,38 & 0,36 & $\mathbf{3 6}$ & $\mathbf{0 , 5 3}$ & $\mathbf{0 , 3 9}$ \\
\hline 7 & 0,30 & 0,19 & $\mathbf{2 2}$ & $\mathbf{0 , 5 3}$ & $\mathbf{0 , 6 2}$ & $\mathbf{3 7}$ & $\mathbf{0 , 4 7}$ & $\mathbf{0 , 5 7}$ \\
\hline $\mathbf{8}$ & $\mathbf{0 , 3 9}$ & $\mathbf{0 , 4 1}$ & 23 & 0,22 & 0,03 & $\mathbf{3 8}$ & $\mathbf{0 , 5 7}$ & $\mathbf{0 , 7 0}$ \\
\hline 9 & 0,47 & 0,33 & $\mathbf{2 4}$ & $\mathbf{0 , 6 9}$ & $\mathbf{0 , 5 7}$ & $\mathbf{3 9}$ & $\mathbf{0 , 4 1}$ & $\mathbf{0 , 6 4}$ \\
\hline $\mathbf{1 0}$ & $\mathbf{0 , 4 3}$ & $\mathbf{0 , 4 6}$ & $\mathbf{2 5}$ & $\mathbf{0 , 5 2}$ & $\mathbf{0 , 6 1}$ & 40 & 0,32 & 0,20 \\
\hline 11 & 0,36 & 0,32 & $\mathbf{2 6}$ & $\mathbf{0 , 5 9}$ & $\mathbf{0 , 7 7}$ & 41 & 0,38 & 0,36 \\
\hline 12 & 0,26 & 0,12 & $\mathbf{2 7}$ & $\mathbf{0 , 6 5}$ & $\mathbf{0 , 6 4}$ & 42 & 0,30 & 0,30 \\
\hline $\mathbf{1 3}$ & $\mathbf{0 , 5 3}$ & $\mathbf{0 , 5 7}$ & $\mathbf{2 8}$ & $\mathbf{0 , 5 7}$ & $\mathbf{0 , 5 7}$ & 43 & 0,33 & 0,14 \\
\hline $\mathbf{1 4}$ & $\mathbf{0 , 7 4}$ & $\mathbf{0 , 4 1}$ & $\mathbf{2 9}$ & $\mathbf{0 , 5 0}$ & $\mathbf{0 , 5 1}$ & 44 & 0,33 & 0,23 \\
\hline $\mathbf{1 5}$ & $\mathbf{0 , 5 0}$ & $\mathbf{0 , 6 2}$ & $\mathbf{3 0}$ & $\mathbf{0 , 6 2}$ & $\mathbf{0 , 7 1}$ & 45 & 0,25 & 0,09 \\
\hline & & & & & Ortalama & & 0,46 & 0,38 \\
\hline
\end{tabular}

*Koyu renk testin son haline seçilen maddeleri ifade etmektedir.

Madde analizi sonucunda $8,10,13,14,15,16,17,19,22,24,25,26,27,28,29,30,31,33$, $34,35,36,37,38$ ve 39 numaralı maddeler 24 maddeden oluşan nihai test için seçilmiştir. Bu sorulardan oluşan testin ortalama güçlüğü 0.54 , ortalama ayırt ediciliği ise 0.57 'dir (Bkz. Tablo 4).

Çevresel vatandaşlık bilgi testinin iç güvenirliğinin tespit edilmesinde KR20 testi kullanılmıştır. KR20 verilerin ikili kategorik (dikotom) olması durumunda tercih edilen iç güvenirlik tekniğidir. Analizi sonucunda iç güvenirlik katsayısı 0.85 olarak tespit edilmiştir. Bu sonuç, sınıf değer olan 0.70 'in oldukça üzerinde olup soruların benzer bir yapıyı ölçtügünü göstermektedir.

\section{Verilerin Analizi}

Verilerin analizinde SPSS ve Excel programları kullanılmıştır. Madde güçlük ve madde ayırt edicilik değerleri Excel üzerinden formül uygulanarak hesaplanmıştır. Madde güvenirliği, madde sıklık dağılımları için ise SPSS programından faydalanılmıştır. Öğrencilerin bilgi düzeyleri Çevresel Vatandaşlık Bilgi Testinin seçilen 24 maddeden aldıkları puanlara göre değerlendirilmiştir.

\section{Bulgular}

Ortaokul öğrencilerinin çevresel vatandaşlık bilgi testinin bütünü ve alt başlıklarından aldıkları puanlara ilişkin betimsel istatistikler Tablo 5 'te yer almaktadır. 
Tablo 5: Öğrencilerin Çevresel Vatandaşlık Bilgi Testinden Aldıkları Puanlara İlişkin Ortalama ve Standart Sapma Değerleri

\begin{tabular}{|l|c|c|c|c|c|c|c|c|}
\hline & $\mathbf{N}$ & \multirow{2}{*}{$\begin{array}{c}\text { Madde } \\
\text { Sayısı }\end{array}$} & $\begin{array}{c}\text { En } \\
\text { Düşük } \\
\text { Puan }\end{array}$ & $\begin{array}{c}\text { Yüksek } \\
\text { Puan }\end{array}$ & \multicolumn{2}{c|}{$\begin{array}{c}\text { Doğru Cevap } \\
\text { Sayısına Göre }\end{array}$} & \multicolumn{2}{|c|}{$\begin{array}{c}\text { 100 Puan } \\
\text { Üzerinden }\end{array}$} \\
\hline Geri Dönüsüm & 255 & 3 &, 00 & 3,00 & 1,37 &, 99 & 45,29 & 32,71 \\
\hline $\begin{array}{l}\text { Tasarruf-Bilinçli } \\
\text { Tüketici }\end{array}$ & 255 & 6 &, 00 & 6,00 & 3,41 & 1,65 & 56,77 & 27,41 \\
\hline $\begin{array}{l}\text { Kirlenme-Çevreyi } \\
\text { Koruma }\end{array}$ & 255 & 9 &, 00 & 9,00 & 5,07 & 2,65 & 56,29 & 29,47 \\
\hline $\begin{array}{l}\text { Küresel Isınma ve } \\
\text { Sera Gazı }\end{array}$ & 255 & 6 &, 00 & 6,00 & 2,55 & 1,66 & 42,53 & 27,59 \\
\hline Toplam Puan & 255 & 24 & 1,00 & 23,00 & 12,40 & 5,56 & 51,65 & 23,17 \\
\hline
\end{tabular}

Öğrencilerin çevresel vatandaşlık bilgi testinin bütününden aldıkları puanların ortalaması $\bar{X}=2.4$ (ss=5.56), en düşük puan 1 en yüksek puan ise 23'tür. Geri dönüşüm alt boyutundan öğrencilerin aldıkları puanların ortalaması $\bar{X}=1.37$ ( $\mathrm{ss}=.99$ ), en düşük puan 0 en yüksek puan ise 3 'tür. Tasarruf-Bilinçli Tüketici alt boyutundan öğrencilerin aldıkları puanların ortalaması $\bar{X}=3.41$ $(\mathrm{ss}=1.65)$, en düşük puan 0 en yüksek puan ise 6'd1r. Kirlenme-Çevreyi Koruma alt boyutundan öğrencilerin aldıkları puanların ortalaması $\bar{X}=5.07$ ( $\mathrm{ss}=2.65$ ), en düşük puan 0 en yüksek puan ise 9'dur. Küresel Isınma ve Sera Gazı alt boyutundan öğrencilerin aldıkları puanların ortalaması $\overline{\mathrm{X}}=2.55$ (ss=1.66), en düşük puan 0 en yüksek puan ise 6'dır. 100 puan üzerinden alınabilecek puanlara göre alt boyutlara bakıldığında öğrencilerin en çok Küresel Isınma ve Sera Gazı alt boyutunda zorlandıkları görülmektedir. Zorluk açısından Geri dönüşüm konusu ikinci sırada olup bunu Kirlenme-Çevreyi Koruma ile Tasarruf-Bilinçli Tüketici konuları izlemektedir. TasarrufBilinçli Tüketici ile Küresel Isınma ve Sera Gazı konularında öğrencilerin puanları 50'nin üzerindedir. Ortalama puanın ise 50'nin çok az üzerinde olduğu görülmektedir.

Tablo 6: Öğrencilerin Çevresel Vatandaşlık Bilgi Testi Maddelerine Verdiklerin Doğru Cevaplara İlişkin Sıklık Dağılımı

\begin{tabular}{|c|c|c|c|c|}
\hline & & & Doğru & na S1klı̆̆ \\
\hline Alt boyut & No & & $\mathrm{N}$ & $\%$ \\
\hline \multirow{3}{*}{ Geri Dönüşüm } & 1 & Maddelerin doğada çözünme süresi & 96 & 37,6 \\
\hline & 2 & Geri dönüşüm oranları & 125 & 49,0 \\
\hline & 3 & Geri dönüșümde Türkiye'nin dünyadaki yeri & 129 & 50,6 \\
\hline \multirow{6}{*}{$\begin{array}{l}\text { Tasarruf- } \\
\text { Bilinçli Tüketici }\end{array}$} & 4 & Tasarruf sembolünü tanıma & 198 & 77,6 \\
\hline & 5 & Elektrik tasarrufu yolları & 130 & 51,0 \\
\hline & 6 & Elektrik tasarrufu yolları & 128 & 50,2 \\
\hline & 7 & Bilinçli tüketici davranışı & 172 & 67,5 \\
\hline & 8 & Bilinçli tüketici davranışı & 129 & 50,6 \\
\hline & 9 & Çevre koruma davranışı & 112 & 43,9 \\
\hline \multirow{9}{*}{$\begin{array}{l}\text { Kirlenme- } \\
\text { Çevreyi } \\
\text { Koruma }\end{array}$} & 10 & Toprak kirliliği nedenleri & 194 & 76,1 \\
\hline & 11 & Çevre kirliliği nedenleri & 125 & 49,0 \\
\hline & 12 & Su kirliliği nedenleri & 152 & 59,6 \\
\hline & 13 & Atıkların zararları & 165 & 64,7 \\
\hline & 14 & Su kirliliği nedenleri & 144 & 56,5 \\
\hline & 15 & Kirliliğin sonuçları & 106 & 41,6 \\
\hline & 16 & Çevre koruma davranışı & 148 & 58,0 \\
\hline & 17 & Kirliliğin sonuçları & 116 & 45,5 \\
\hline & 18 & Çevreci birey davranış1 & 142 & 55,7 \\
\hline \multirow{2}{*}{$\begin{array}{l}\text { Küresel Isınma } \\
\text { ve Sera Gazı }\end{array}$} & 19 & Karbondioksit miktarını arttıran nedenler & 92 & 36,1 \\
\hline & 20 & Sera etkisi nedenleri & 129 & 50,6 \\
\hline
\end{tabular}




\begin{tabular}{|l|l|l|c|c|}
\hline & 21 & Sera etkisi nedenleri & 103 & 40,4 \\
\cline { 2 - 5 } & 22 & Küresel Isınmanın nedenleri & 102 & 40,0 \\
\cline { 2 - 5 } & 23 & Karbondioksit miktarını arttıran nedenler & 127 & 49,8 \\
\cline { 2 - 5 } & 24 & Sera etkisi tanımı & 98 & 38,4 \\
\hline \multicolumn{1}{|l|}{ Toplam } & & 255 & 100 \\
\hline
\end{tabular}

Geri Dönüşüm alt boyutunda bulunan üç sorudan ikisine öğrencilerin yarısı doğru cevap verirken birine \%37,6's1 doğru cevap verebilmiştir. Diğerlerine göre öğrencileri daha az bilgi sahibi oldukları bu soru farklı maddelerin doğada çözünme sürelerine ilişkin bilgiyi ölçmektedir. TasarrufBilinçli Tüketici alt boyutunda doğru cevaplama oranı geri dönüşüm boyutundan biraz daha yüksektir. Bir soru dışında öğrencilerin yarıdan fazlası sorulara doğru cevap verebilmiştir. Yüksek oranda doğru cevap verilmiş olması soruların büyük çoğunluğunun evdeki tasarruf uygulamalarına yönelik olmasıyla açıklanabilir. Öğrencilerin daha düşük oranda doğru cevap verdikleri soru ise genel olarak çevre korumaya yönelik davranış bilgi düzeyini ölçmektedir. Kirlenme-Çevreyi Koruma boyutunda ise dokuz sorudan üçüne yarıdan az cevap verilmiş iken altısında yarıdan fazlası doğru cevap verilmiştir. Küresel Isınma ve Sera Gazı alt boyutu ise sadece bir soruya öğrencilerin yarısı doğru cevap vermiş kalan beş soruda ise doğru cevap oranı yüzde 40'lar civarında kalmıştır. $\mathrm{Bu}$ sorulara verilere cevaplardan öğrencilerin küresel 1sınma ve sera etkisi konusundaki bilgi düzeylerinin diğer alanlara göre daha düşük olduğunu göstermektedir.

\section{Tartışma ve Sonuç}

Dünyada nüfusun hızla artması, buna paralel olarak enerji, gıda, barınma, taşıma ihtiyaçlarının da artmasına yol açmıştır. Tüm bu ihtiyaçların karşılanma sürecinin sonuçları doğanın daha fazla kirlenmesi, küresel ısınmanın hızlanması ile sonuçlanmıştır. Çevrenin korunmasında devletlerin aldığı tedbirler yanında bireylerin kendi çabalarının da büyük katkısı bulunmaktadır. Çevreyi korumak duyuşsal bir süreç olmasına rağmen öncelikle neler yapılması gerektiğine ilişkin bilgi sahibi olunması gerekir. Çevre bilincinin kazandırılması için küçük yaşlardan itibaren bireyleri bilgi ve tutum kazandırılmasına yönelik çalışmalar yapılmalıdır. Bu çalışmada çevresel vatandaşlık kapsamında yedinci ve sekizinci sınıf öğrencilerinin sahip oldukları bilgiler ölçülmüştür. Ulaşılan sonuçlar araştırmaya katılan çocukların bilgi düzeylerinin orta seviye olduğunu göstermektedir. Öğrenciler küresel ısınma ve sera gazı konusunda diğer konulara göre daha az bilgi sahibidirler. $\mathrm{Bu}$ sonuç küresel ısınma ve sera gazı konusunun sekizinci sınıfta görülecek olmasından kaynaklanmış olabilir. Öğrencilerin orta değerin altında bilgiye sahip oldukları diğer bir konu ise geri dönüşümdür. Yine bu sonuç da konu yedinci sınıfta olmasına rağmen öğrencilerin uygulamanın yapıldı̆̆ 1 tarihte öğrenciler konuyu görmemiş olmaları olabilir. Tasarruf-Bilinçli Tüketici ile Kirlenme-Çevreyi Koruma konuları önceki sınıflarda görülmüş oflamalarına ve günlük hayatta da sıklıkla karşılaşılan konular olmasına rağmen öğrencilerin bilgi düzeyleri ortanın biraz üzerinde kalmıştır. Bu sonuçlara göre örgün eğitimin bilgi düzeyine katkısının çok yüksek olmadığı söylenebilir. Genel olarak bakıldığında öğrencilerin bilgilerinin yetersiz olduğu söylenebilir. Sönmez ve Yerlikaya'nın (2017) sekizinci sınıflar üzerinde yapmış oldukları araştırmada da öğrencilerin çevresel bilgi düzeyleri test ortalamasının biraz üzerinde çıkmıştır. Bu sonuç örgün eğitimin çevresel bilgi düzeyini artırmadaki yetersizliğine ilişkin görüşü desteklemektedir. Esen (2011) çalışmasında 4., 5., 6., 7. ve 8. sınıfa devam eden üstün yetenekli öğrencilerin çevresel bilgi düzeyini ölçmüştür. Öğrencilerin başarı puanları 100 üzerinden 70 olarak tespit edilmiştir. Sınıflar arasında ise çevresel bilgi düzeyleri açısından çok az farklılık tespit edilmiştir. Sağır, Aslan ve Cansaran (2008) tarafindan 7. ve 8. Sınıflar üzerinde yapılan araştırmada öğrencilerin başarı düzeyleri ortalama olarak tespit edilmiştir. 7. Sınıfların bilgi düzeyleri 8. sınıflardan anlamlı derecede daha yüksek olarak tespit edilmiştir. Bilgi düzeyleri ölçüldüğünde öğrencilerin yeterli bilgiye sahip olmadıkları anlaşılmaktadır. Bunun yanında Vural ve Yılmaz (2016) öğrencilerin çevresel bilgileri için algılarını ölçmüştür. Bu çalışmada öğrenciler çevresel bilgi düzeylerinin oldukça yüksek olduğunu ifade etmişlerdir. Ünlü,

Turkish Studies - Education, 15(2) 
Sever ve Akpınar (2011) yaptıkları metasentez çalışmasında Küresel Isınma ve Sera Etkisi konulu akademik çalışmaları incelemişlerdir. Çalışma sonucuna göre incelenen araştırmalarda katılımcıların Küresel ısınma ve sera etkisi konusunda eksik ve yanlış bilgilere sahip oldukları tespit edilmiştir. Elde edilen bir sonuç da eğitim seviyesi yükselmesine rağmen bilgi düzeyinde anlamlı bir gelişmenin olmamasidir.

Her ne kadar davranış değişikliği ve gelişimi birçok öğretim programının birincil hedefi olsa da, bu amaçlara en iyi şekilde nasıl ulaşılacağı konusunda açık bir anlayış hala gelişmektedir. Çevresel vatandaşlık kavramı bireyler tarafindan genellikle çevresel sorunlara karşı duyarlılık ve sorumlu çevresel davranıșlarda bulunma olarak algılanmaktadır. Bu dar bakıș açısı çevresel sorunlar ile ilgili kavramsal bilginin önemini ihmal etmektedir. Çevre bilinci genelde çevre temizliği ve doğayı koruma olarak algılanmaktadır (Aydın, 2010; Yağlıkara, 2006). Bu durumun öğretmen ve öğrenci algılarında benzerlik gösterdiği ve kamuoyunun aile, kitle iletişim araçları, görsel ve işitsel medya ve sivil toplum örgütlerini çevresel vatandaşlık eğitiminin ana kanalları olarak gördügü rapor edilmiştir (Süyün, 2010). Ülkemizde çevre eğitimi Hayat Bilgisi, Sosyal Bilgiler ile Fen ve Teknoloji derslerinde verilmektedir. Araştırmalar ilköğretim düzeyinde öğrencilerin çevre kavramları bilgi düzeylerinin düşük (Armağan, 2006; Yüksel, 2009) ortaöğretim düzeyindeki öğrencilerin bilgi düzeylerinin ise orta (Varışl1, 2009) düzeyde olduğunu ortaya koymuştur. Bu çalışmanın bulguları alan yazındaki çalışmaların bulguları ile kısmen örtüşmektedir. Öğrencilerin çevresel kavramlar bilgi düzeylerinin yaşları ile birlikte arttı̆̆ 1 da tartışılmıştır (Erdoğan, 2009). Çalışmada geliştirilen test ortaokul öğrencilerinin çevresel vatandaşlık düzeylerinin bilgi boyutunu ölçmek için geçerli ve güvenilir bir ölçektir. Çevre Vatandaşlığı Bilgi Testi çevre eğitiminde çeşitli araştırmacılar tarafından ifade edilen, sağlam psikometrik özelliklere sahip bir ölçme aracı için olan ihtiyacı karşılamaktadır. Bilgi testi çeşitli araştırma ortamlarında kullanılabileceği gibi bu çalışmaların sonuçlarının karşılaştırılabilir olmasına imkân sağlayacaktır.

\section{Kaynakça}

Armağan, F. Ö. (2006). İlkögrretim 7-8. sinlf ögrencilerinin çevre eğitimi ile ilgili bilgi düzeyleri (Kırıkkale il merkezi örneklemi). Yayınlanmamış yüksek lisans tezi, Gazi Üniversitesi, Eğitim Bilimleri Enstitüsü, Ankara. "https://doi.org/10.1501/egifak_0000001364"

Artun, H. (2013). Yedinci sinıf ögrencilerinin çevre eğitimine yönelik tasarlanan modüler öğretim programının etkililiğinin araştırılması. Yayınlanmamış Doktora Tezi. Karadeniz Teknik Üniversitesi, Trabzon.

Atasoy, E. (2005). Çevre içi eğitim: ilköğretim öğrencilerinin çevresel tutum ve çevre bilgisi üzerine bir çalışma. Ege Ĕ̈itim Dergisi, 18(2) , 774-794 "https://doi.org/10.12984/egeefd.315404"

Aydın, G. (2010). Fen-teknoloji-toplum-çevre ögrrenme alanının çevre bilinci kazandırmasına ilişkin sınıf öğretmenlerinin görüşleri. Yayınlanmamış yüksek lisans tezi, Anadolu Üniversitesi, Eğitim Bilimleri Enstitüsü, Eskişehir. "https://doi.org/10.19171/uuefd.93591"

Bahar, M. (2000). Üniversite ögrencilerinin çevre eğitimi konularındaki ön bilgi düzeyi, kavram yanılgıları, V. Uluslararası Ekoloji ve Çevre Sorunları Sempozyumu. Tübitak, Ankara.

Büyüköztürk, Ş., Çakmak, E. K., Akgün, Ö. E., Karadeniz, Ş., ve Demirel, F. (2017). Bilimsel araşttrma yöntemleri. Ankara: PegemA. "https://doi.org/10.14527/9789944919289"

Cheah, S. L., \& Huang, L. (2019). Environmental citizenship in a nordic civic and citizenship education context. Nordic Journal of Comparative and International Education (NJCIE), 3(1), 88-104. "https://doi.org/10.7577/njcie.3268"

Creswell, J. W. (2013). Araştırma deseni. Ankara: Eğiten Kitap.

Erdoğan, M. (2009). Fifth grade students' environmental literacy and the factors affecting students' environmentally responsible behaviors (5. sinıf ögrencilerinin çevre okuryazarlığl ve bu ögrencilerin çevreye yönelik sorumlu davranışlarını etkileyen faktörler). Yayınlanmamış 
doktora tezi, Orta Doğu Teknik Üniversitesi, Sosyal Bilimler Enstitüsü, Ankara. "https://doi.org/10.20875/makusobed.415954"

Erentay, N. (2013). Okul dışı doğa uygulamalarının 5. sınıf ögrencilerinin fen'e ilişkin bilgi, bilimsel süreç becerilerine ve çevreye yönelik tutumlara etkisi. Yayınlanmamış yüksek lisans tezi, Akdeniz Üniversitesi, Eğitim Bilimleri Enstitüsü, Antalya. "https://doi.org/10.15285/maruaebd.271564"

Erkan, S., ve Gömleksiz, M. (2014). Ĕ̈itimde ölçme ve değerlendirme. Ankara: Anı Yayıncılık

Esen, T. (2011). Üstün yetenekli ögrencilerin çevreye yönelik bilgi ve tutumlarının incelenmesi. Yayınlanmamış Yüksek Lisans Tezi. Adıyaman Üniversitesi. Adıyaman.

Hadjichambis, A. Ch., Paraskeva-Hadjichambi D., Reis, P., Knippels, M.C., Christodoulou A., Xhindi, N., Sokoli, E., Lapin, K., Leregger, F., Zoescher, J., Zabic, M., Gekic, H., Keranova, D., Manov, B., Sulc, I., Gasparovic, S., Sladonja, B., Poljuha, D., Balmon, T., Garnier, B., Kalaitzidaki, M., Farangitakis, G., Paschalidou, A. Sbarounis, T., Megyesi, B., Csizmady, A., Kovách, I., Ferencz, Z., Finger, D.C., Conti, D., Baglivo, L., Sartoretti, C., Minz, K., Weinstein, Z., Goldman, D., Sarid, A., Telešienè, A., Balžekienè, A., Balundè, A., Petrusic (Bilafer), I., Perunicic, S., Jovanovic, J., Lenhardt, M., Radovic, V., Djokic, V., Djordjevic, Z., Cujic, M., Kaputa, V., Paluš, H., Mat’ová, H., Šupín, M., Oset, Z., Kovič Dine, M., Parra Anguita, M.G., Delgado Jiménez, A., Romero Ariza, M., Oral, H.V., Erses Yay, A.S., Cermik, E. (2019). Education for environmental citizenship in focus (in English). Lemesos, Cyprus: European Network for Environmental Citizenship - ENEC Cost Action.

Hadjichambis, C., \& Paraskeva-Hadjichambi, D. (2020). Environmental citizenship questionnaire (ecq): the development and validation of an evaluation instrument for secondary school students. Sustainability, 12(3), 821. "https://doi.org/10.3390/su12030821"

Hawthorne, M., \& Alabaster, T. (1999). Citizen 2000: Development of a model of environmental citizenship. Global Environmental Change, 9(1), 25-43. "https://doi.org/10.1016/s09593780(98)00022-3"

Jeffries, H., Stanisstreet, M., \& Boyes, E. (2001). Knowledge about the 'Greenhouse Effect': have college students improved?. Research in Science \& Technological Education, 19(2), 205221. "https://doi.org/10.1080/02635140120087731"

MEB, (2013). Fen ve teknoloji programı. Ankara: Milli Eğitim Bakanlığı (MEB) Yayınları.

Mete, A. (2014). Illkögretim ögrencilerinin çevreye yönelik bilgi ve tutumlarına çevre koruma kulübü’nün etkisi. Yayınlanmamış Yüksek Lisans Tezi. Eskişehir Orhangazi Üniversitesi. Eskişehir. "https://doi.org/10.7827/turkishstudies.8688"

Sağır, Ş. U., Aslan, O., ve Cansaran, A. (2008). İlköğretim öğrencilerinin çevre bilgisi ve çevre tutumlarının farklı değişkenler açısından incelenmesi. Ilköğretim Online, 7(2), 496-511. "https://doi.org/10.17051/ilkonline.2017.330249"

Schild, R. (2016). Environmental citizenship: What can political theory contribute to environmental education practice?. The Journal of Environmental Education, 47(1), 19-34. "https://doi.org/10.1080/00958964.2015.1092417"

Soran, H., Morgil, F. İ., Yücel, S., Atav, E., \& Iş̧1k, S. (2000). Biyoloji öğrencilerinin çevre konularına olan ilgilerinin araştırılması ve kimya ögrencileri ile karşılaştırılması. Hacettepe Üniversitesi Eğitim Fakültesi Dergisi, 18(18). "https://doi.org/10.17556/jef.93507"

Sönmez, E, ve Yerlikaya, Z . (2017). Ortaokul öğrencilerinin çevresel bilgi düzeyleri ve çevreye yönelik tutumları üzerine bir alan araştırması: Kastamonu ili örneği. Kastamonu Eğitim Dergisi, 25(3), 1239-1249 .

Süyün, B. (2010). İlkögretim ögrencilerinin çevreye yönelik bilinç ve algılamaları. Yayınlanmamış yüksek lisans tezi, Marmara Üniversitesi, Eğitim Bilimleri Enstitüsü, İstanbul 
Şahin, F., \& Yazgan, B. S. (2013). Araştırmaya dayalı sınıf dışı laboratuar etkinliklerinin öğrencilerin akademik başarısına etkisi. Sakarya University Journal of Education, 3(3), 107-122.

Şahin, K., \& Gül, S. (2009). Ortaöğretim ögrencilerinin çevre bilgisi, davranışı ve duyarlılıklarının araştırılması: Samsun örneği. Kastamonu Eğitim Dergisi, 17(2), 541-556.

UNCED. (1992). The earth summit, agenda 21: Programme of action for sustainable development. report of the united nations conference on environment and development (UNCED). Rio de Janeiro, 3-14 June. Brazil. "https://doi.org/10.1007/springerreference 29770"

UNESCO-UNEP. (2010). Declaration of the United Nations Conference on the Human Environment,http://www.unep.org/Documents.Multilingual/default.asp?DocumentID=97\& ArticleID $=1503 \& \mathrm{l}=\mathrm{en}, 10.05 .2010$.

Uzun, N. ve Sağlam, N., (2006). Orta öğretim öğrencileri için çevresel tutum ölçeği geliştirme ve geçerliliği. Hacettepe Üniversitesi Eğitim Fakültesi Dergisi, 30, 240-250. "https://doi.org/10.17679/inuefd.300688"

Ünlü, İ., Sever, R., ve Akpınar, E. (2011). Türkiye'de çevre eğitimi alanında yapılmış küresel ısınma ve sera etkisi konulu akademik araştırmaların sonuçlarının incelenmesi. Erzincan Üniversitesi Eğitim Fakültesi Dergisi, 13(1), 39-54. "https://doi.org/10.17240/aibuefd.2017.17.32772-363962"

Varışl1, T. (2009). Evaluatıng eighth grade students' environmental literacy: The role of sociodemographıc varıables (Sekizinci sinıf öğrencilerinin çevre okuryazarlı̆̆ının değerlendirilmesinde sosyodemografik değişkenlerin rolü). Yayınlanmamış yüksek lisans tezi, Orta Doğu Teknik Üniversitesi, Sosyal Bilimler Enstitüsü, Ankara.

Vural, H., ve Yılmaz, S. (2016). Ortaokul öğrencilerinin çevre ve doğa ile ilgili konularda bilgi ve davranıș düzeylerinin belirlenmesi; Erzurum ili örneği. Iğdır Üniversitesi Fen Bilimleri Enstitüsü Dergisi, 6(1), 107-115. "https://doi.org/10.30910/turkjans.471208"

Yağlikara, S. (2006). Okulöncesi dönem çocuklarına çevre bilinci kazandırmada fen ve doğa etkinliklerinin etkileri konusunda ögretmen görüşleri. Yayınlanmamış yüksek lisans tezi, Anadolu Üniversitesi, Eğitim Bilimleri Enstitüsü, Eskişehir.

Yılmaz, A., Morgil, F. İ., Aktuğ, P., \& Göbekli, İ. (2002). Ortaöğretim ve üniversite öğrencilerinin çevre, çevre kavramları ve sorunları konusundaki bilgileri ve öneriler. Hacettepe Üniversitesi Eğitim Fakültesi Dergisi, 22(22).

Yücel, A. S. ve Morgil, İ. (1998). Yükseköğretimde çevre olgusunun araştırılması. Hacettepe Üniversitesi Ë̆itim Fakültesi Dergisi, 14, 84-94.

Yüksel, Y. (2009). Klasik okullar ile eko-okullar ve yeşil bayrakl eko okulların çevre eğitimi açısından karşılaştırılması. Yayınlanmamış yüksek lisans tezi, Gazi Üniversitesi, Eğitim Bilimleri Enstitüsü, Ankara. "https://doi.org/10.17860/mersinefd.391312" 


\section{Ek: Çevresel Vatandaşlık Bilgi Testi}

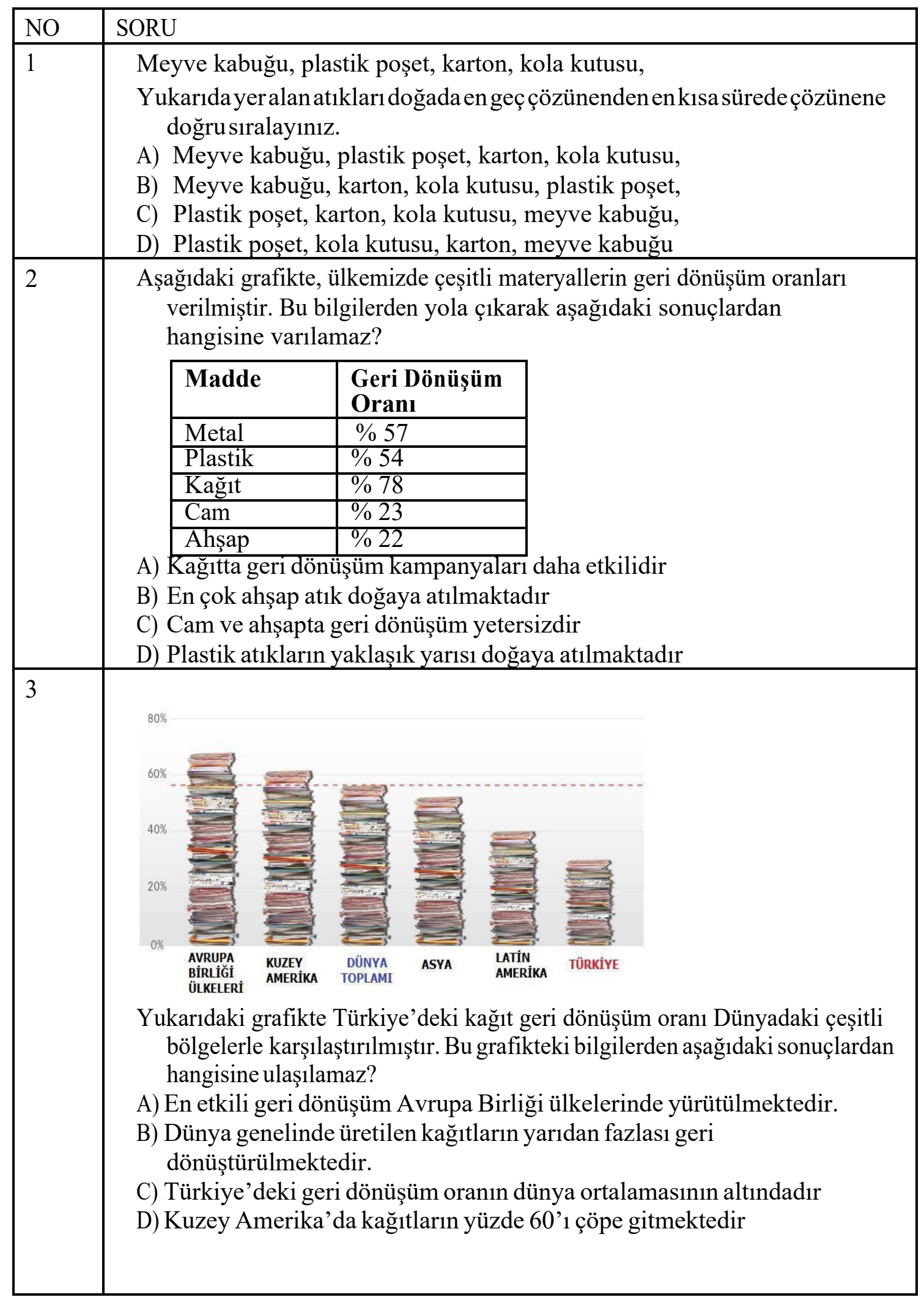




\begin{tabular}{|c|c|}
\hline 4 & $\begin{array}{l}\text { At++ } \\
A^{++} \\
\text {Cukarıdaki şekil neyi temsil etmektedir? } \\
\text { A) Elektrik tasarrufunu } \\
\text { B) Alfabeyi } \\
\text { C) Sicaklığ1 } \\
\text { D) Yeryüzü şekillerini }\end{array}$ \\
\hline 5 & $\begin{array}{l}\text { I- Elektrikli araçları hazırda bekletme (standby) modunda bırakmamak } \\
\text { II- Şarj aletini prizde takılı bırakmamak } \\
\text { III- Kullanılmayan odaların ışı̆̆ını kapatmak } \\
\text { IV- Klimayı } 24 \text { dereceden aşağıya almamak } \\
\text { Yukarıdakilerden hangileri elektrik tasarrufu sağlar? } \\
\text { A) I-II } \\
\text { B) I-III-IV } \\
\text { C) III-IV } \\
\text { D) Hepsi }\end{array}$ \\
\hline 6 & $\begin{array}{l}\text { Elektrik tasarrufu yaparak hem çevreyi korumak hem de aile ekonomisine } \\
\text { katkıda bulunmak mümkündür. Aşağıdakilerden hangisi evde elektrik } \\
\text { tasarrufu yapan birisinin yapacağı davranış değildir? } \\
\text { A) A sınıf elektrikli eşya almak } \\
\text { B) Klimayı } 24 \text { derecede tutmak } \\
\text { C) Led lamba satın almak } \\
\text { D) TV yi hazırda bekletme (standby) konumunda bırakmak }\end{array}$ \\
\hline 7 & $\begin{array}{l}\text { Aşağıdakilerden hangisi bilinçli tüketicinin yapacağı işlemlerden birisidir? } \\
\text { A) Marketten canı ne isterse onu almak } \\
\text { B) Yurtdışından gelen ürünleri tercih etmek } \\
\text { C) Markete gitmeden alışveriş listesi hazırlamak } \\
\text { D) Damacana su yerine pet şişe almak }\end{array}$ \\
\hline 8 & $\begin{array}{l}\text { Bilinçli bir tüketici olmak için çaba harcayan Elif, aşağıdakilerden hangisini } \\
\text { yaparsa bu çabasına uygun davranmamış olur? } \\
\text { A) Okuma kitaplarını arkadaşlarıyla paylaşırsa } \\
\text { B) Oynamadığı oyuncakları ihtiyacı olanlara verirse } \\
\text { C) Odadan ayrılırken ışığı kapatırsa } \\
\text { D) Servis yerine babasının bırakmasını isterse }\end{array}$ \\
\hline
\end{tabular}




\begin{tabular}{|c|c|}
\hline 9 & $\begin{array}{l}\text { Çevreyi koruma bilincinde olan bir kişi aşağıdakilerden hangisini yapar? } \\
\text { A) Toplu taşıma araçlarını kullanır } \\
\text { B) Çevreye atık maddeleri atar } \\
\text { C) Aldığı ürünlerin sadece ucuz olmasına bakar } \\
\text { D) Atıkları tek poşete koyar }\end{array}$ \\
\hline 10 & $\begin{array}{l}\text { Aşağıdakilerden hangisi toprak kirliliğine neden olur? } \\
\text { A) Çöp veçöpyı̆̆ınları } \\
\text { B) Ormanların artması } \\
\text { C) Bitkilerin artması } \\
\text { D) Sis oluşması }\end{array}$ \\
\hline 11 & $\begin{array}{l}\text { Çevre kirliliğine neden olan temel etken aşağıdakilerden hangisidir? } \\
\text { A) Küresel ısınma } \\
\text { B) İnsan faaliyetleri } \\
\text { C) Bitkilerin azalması } \\
\text { D) Plansız şehirleşme }\end{array}$ \\
\hline 12 & $\begin{array}{l}\text { Aşağıdakilerden hangisi su kirliliğinin sonuçlarından biri değildir? } \\
\text { A) Akarsuların kirlenmesi } \\
\text { B) Denizde yaşayan canlıların toplu ölümleri } \\
\text { C) İçme sularının kirlenmesi } \\
\text { D) Sis oluşumu }\end{array}$ \\
\hline 13 & $\begin{array}{l}\text { Aşağıdaki yapılan davranışlardan hangisi atıklarla çevreye zarar verir? } \\
\text { A) Lavaboya sıvı atık yağ dökmek } \\
\text { B) Plastik ürünleri geri dönüşüm kutusuna atmak } \\
\text { C) Bitki atıklarından gübre yapılması } \\
\text { D) Pillerin toplanarak geri dönüştürülmesi }\end{array}$ \\
\hline 14 & $\begin{array}{l}\text { Aşağıdakilerden hangisi su kirliliğine sebep olmaz? } \\
\text { A) Fabrika atıkları } \\
\text { B) Bitki atıkları } \\
\text { C) Kanalizasyon suları } \\
\text { D) Ev atıklar }\end{array}$ \\
\hline 15 & $\begin{array}{l}\text { Aşağıdakilerden hangisi atık suların filtrelenmeden direkt nehir ve denizlere } \\
\text { akıtılmasının sonuçlarından birisi değildir? } \\
\text { A) Denizdeki canlıların zehirlenmesine yol açar } \\
\text { B) Biyoçeşitlilik artar } \\
\text { C) Karbondioksit emilimi azalır } \\
\text { D) İçme suları zehirlenir }\end{array}$ \\
\hline
\end{tabular}




\begin{tabular}{|c|c|}
\hline 16 & $\begin{array}{l}\text { Çevrenin korunması için aşağıdakilerden hangisinin yapılması doğru } \\
\text { değildir? } \\
\text { A) Enerji tasarruflu elektrikli araç ve gereç kullanmak } \\
\text { B) Çöpleri geri dönüşüm özelliklerine göre ayırmak } \\
\text { C) Suyu tasarruflu kullanmak } \\
\text { D) Yabani hayvanların sayısınıazaltmak }\end{array}$ \\
\hline 17 & $\begin{array}{l}\text { Rastgele atılmış çöpler hem insan hem de diğer canlıların ve bitkilerin yaşam } \\
\text { alanları için bir tehdit unsurudur. Aşağıdakilerden hangisi çöplerin yaşam } \\
\text { alanları olumsuz etkilerden biri değildir? } \\
\text { A) Toprak kaymasına yolaçmak } \\
\text { B) Toprağın kirlenerek veriminin azalmasına yol açmak } \\
\text { C) Su kaynaklarının kirlenmesine yol açmak } \\
\text { D) Hastalıkların ortaya çıkmasına ve yayılmasına yol açmak }\end{array}$ \\
\hline 18 & $\begin{array}{l}\text { Aşağıdakilerden hangisi çevreye duyarlı bir vatandaşın davranışı olamaz? } \\
\text { A) Su kullanımında tutumlu davranmak } \\
\text { B) Geri dönüşümlü ürünleri tercih etmek } \\
\text { C) Toplu taşıma yerine özel arabasını kullanmak } \\
\text { D) Az enerji tüketen elektrikli aletleri almak }\end{array}$ \\
\hline 19 & $\begin{array}{l}\text { Așağıdakilerden hangisi havadaki karbondioksit miktarını arttıran olaylardan } \\
\text { biri değildir? } \\
\text { A) Fotosentez } \\
\text { B) Solunum } \\
\text { C) Yanma } \\
\text { D) Fosil yakıt tüketimi }\end{array}$ \\
\hline 20 & $\begin{array}{l}\text { Sera etkisi aşağıdakilerden hangisinin bir sonucudur? } \\
\text { A) Hava kirliliği } \\
\text { B) Su kirliliği } \\
\text { C) Toprak kirliliği } \\
\text { D) Nükleer kirlilik }\end{array}$ \\
\hline 21 & $\begin{array}{l}\text { Aşağıda verilen, atmosferde yer alan gazların hangisinin artması sera etkisine } \\
\text { neden olur? } \\
\text { A) Karbondioksit } \\
\text { B) Oksijen } \\
\text { C) Hidrojen } \\
\text { D) Azot }\end{array}$ \\
\hline 22 & $\begin{array}{l}\text { Aşağıdakilerden hangisi küresel ısınmanın sebepleri arasında gösterilemez? } \\
\text { A) Ormanların azalması } \\
\text { B) Aşırı nüfus artışı } \\
\text { C) İnsanların tüketim alışkanlıklarındaki artış } \\
\text { D) Fosil yakıtların tüketiminin azaltılması }\end{array}$ \\
\hline
\end{tabular}




\begin{tabular}{|l|l|}
\hline 23 & Aşağıdakilerden hangisi karbondioksit salınımını artıran etkenler arasında yer \\
& alır? \\
& A) Kullanılmış kızartma yağlarının geri dönüşüme gönderilmesi \\
& B) Otomobil sayısının artması \\
C) Ağaç dikilmesi \\
D) Fabrikalara filtre takılması
\end{tabular}

